\title{
Violence in New Mexico: A Sociological Perspective
}

\author{
Clark S. Knowlton*
}

In an era when violence is becoming a more frequent response of minority groups to their unique legal problems, Professor Knowlton probes the causes of a violent incident involving Spanish-Americans in New Mexico in 1967. He discusses, from the perspective of a sociologist, the numerous and complex causes of the historical conflict between Anglo-Americans and Spanish Americans. More specifically, he discusses the various ways in which the Spanish Americans have been deprived of their land and the failure of the legal system to adequately protect their rights. He describes how racial prejudice, violence, corruption, a dearth of legislative imagination, and an unfamiliar legal system have combined to deprive Spanish Americans of millions of acres of land and leave them destitute. Unable to protect their rights by legal methods, many Spanish-Americans have sought leaders among those who advocate and practice violent solutions. Professor Knowlton concludes that further violence can be expected unless the Anglo-American legal system becomes more responsive by incorporating Spanish-American concepts of land ownership and honoring Spanish-American land claims.

On June 5, 1967, a score of armed men drove up to the dilapidated two-story courthouse in the half-abandoned Spanish-American village of Tierra Amarilla, the mountainous county seat of impoverished Rio Arriba County, New Mexico. In the courthouse, Federal District Judge Paul S. Scarborough was finishing the arraignment of seven members of the Alianza Federal de Mercedes-Federal A1liance of Land Grantees ${ }^{1}$ - who had been charged with attending an illegal assembly. The defendants, their attorneys, and courtroom spectators were leaving the courthouse as the armed men entered the building. A young state police officer was shot through the arm and chest when his hand moved down toward his gunbelt. A deputy sheriff who saw the shooting jumped out of the winow and, hit by a bullet,

* Professor of Sociology, Director of the Center for the Study of Social Problems, University of Utah. B.A. 1947, M.A. 1948, Brighan Young University; Ph.D. 1955, Vanderbilt University.

1. Akers, The Alianza Like All Such Movements Began as a Figment of a Man's Imagination, The New Mexican, June 11, 1967, at A-3, col. 1. 
fell wounded to the sidewalk in front of the courthouse. The sheriff and an under-sheriff were struck over the head with pistols and then herded with other public employees and visitors who were caught in the building into a large rooin. Judge Scarborough locked himself, a court reporter, and an attorney in the judge's chambers where they remained undetected. After the raiders had futilely searched the courthouse for the district attorney and the defendants, they shot up several police cars, ripped telephones from the walls, and demolished a twoway police radio. The raiders then left the building with two hostages, a newspaper reporter and a deputy sheriff. The raiders later released the hostages and escaped into the hills. Within a few lours the largest manhunt in New Mexico history was organized. Three hundred and fifty National Guardsmen, 150 State Pohice, 24 members of the New Mexico Mounted Patrol, and the Apache Tribal Police froin Dulce, New Mexico, were mobilized. ${ }^{2}$ The leaders of the raiders, Reies Lopez Tijerina, ${ }^{3}$ and the Alianza Federal de Mercedes captured national

2. The New Mexican, June 6, 1967, at A-1, col. 1; id., June 6, 1967, at A-5, col.1; id., June 6, 1967, at A-3, col. 1; Albuquerque Tribune, June 6, 1965, at A-1, col. 7; Denver Post, June 6, 1967, at 1, col. 3; id., June 6, 1967, at 3, col. 1; El Paso Herald Post, June 6, 1967, at B-4, col. 1; El Paso Times, June 6, 1967, at A-1, col. 8; The New Mexican, June 7, 1967, at A-1, col. 1; id., June 7, 1967, at A-1, col. 7; N.Y. Times, June 7, 1967, at 1, col. 1 .

3. The author has known Reies Lopez Tijerina intimately since 1964 and has spoken at Alianza meetings and interviewed Tijerina and other leaders of the Alianza frequently. Because of his frieudly relationships with the Alianza, the author was called upon by state officials after the raid to serve as a mediator between the Alianza and the state government to assist in preventing additional violence.

The only available material on the life of Reies Lopez Tijerina is what he chooses to reveal. Born September 21, 1923, into a migrant family at New Falls City, Texas, he lost his mother at an early age. Tijerina's crippled father, thrice widowed, with ten children to support, was a migrant worker in the Southwest and Midwest. Though seldom speaking of his inild-mannered father, Tijerina expresses great admiration for his paternal great-grandfather and his grandfather. His great-grandfather ranched on a land grant near Laredo, Texas, trading horses and cattle. In an attempt to steal his land, Anglo-American ranchers drove branded cattle onto it and accused him of rustling. He was hanged by the Texas Rangers while his family watched. His son, Tijerina's grandfather, became a border raider, attacking Anglo-American ranches and settlements along the Mexican border.

The New Testament changed the course of Tijerina's life. He read with intense interest a copy left with his family by a Baptist inissionary in a inidwestern migrant labor camp. One night after reading the book, he dreamed that God had called him to lead his people out of poverty and bondage. Several years later, he enrolled in the Assembly of God Bible School at Ysleta, Texas. Upon being licensed as a minister, he was called to Santa $\mathrm{Fe}$ to assist in a revial. A fiery magnetic speaker, he soon attracted a following. He claims that his credentials as a minister were revoked because he told the people that the poor should not contribute to the church but rather the church should contribute to the poor.

Soinewhat disoriented, he wandered through northern New Mexico, working at odd jobs and talking to the people. He then settled down in Tierra Amarilla and married a local girl. It is highly possible that he joined one of the several seini-secret anti-Anglo- 
headlines. ${ }^{4}$

Little attention, however, was directed toward the basic cause of the raid-the growing hostility and frustration felt by Spanish Americans because of their apparent inability to obtain adequate relief from the courts in recurrently litigating the question of ownership of Spanish and Mexican land grants in New Mexico. Although titles to the land grants have been contested for over 100 years, they are still unsettled and land grant litigation presently occupies a major part of the state and federal court calendars in New Mexico. The court decisions and legislative enactments attenpting to settle the question of land grant ownership have resulted in an increasing transfer of ownership from Spanislı Americans to Anglo-Americans by stifling Spanish-American atteinpts to protect existing land-holdings and to recover lost lands. The inability of the Spanish Americans to secure adequate redress in the court and legislative chambers has caused a deeply rooted cynicisin toward the American legal and political systems and the values upon which they are based. The failure of the courts and

American societies existing around Tierra Amarilla at the time. Several years later, he left northern New Mexico with his wife and children. As an independent Pentecostal minister, he and his family wandered for 13 years through the Midwest and the West as migrant workers. Finally in 1957, he led a devoted following of 17 families to Arizona. Buying a piece of land near Casa Grande, the sinall sect built homes, erected a church, and worked in the surrounding cotton fields. Trouble broke out with neighboring Anglo-American farmers and ranchers, and the little settlement was burned. Tijerina fled the state after being indicted for trying to free his jailed brother, Margarito. During his trial, he walked away from the courthouse during a recess and vanished into Mexico.

Tijerina lived in Mexico for six years. During this time, he clains to have studied the background and history of the Spanish and Mexican land grants in New Mexico. Somewhere he did manage to acquire a considerable amount of knowledge about them. Soine evidence exists that he worked with militant Mexican peasant groups during this period, and as a result was deported to the United States.

Returning to Tierra Amarilla, he came not as a minister, but as a social reforner and organizer. It was inevitable that he would become embroiled in the chronic land disputes characteristic of the region. Bitterness and resentunent over land loss have always burned hotly in Tierra Amarilla. The Tierra Amarilla land grant on which the town and neighboring communities were located was acquired through fraud by certain prominent Anglo-American pobitical leaders in the last half of the 19th century. The land was later sold to Anglo-American land and cattle companies who have tried to clear the land of its Spanish-American inhabitants. In retaliation, the Spanish Americans

have periodically cut fences, burned ranch buildings, and killed Anglo-Americau owncd

livestock. Becouning a leader among the militant Spanish Americans, Tijerina's life was threatened by angry Anglo-American ranchers. His life in danger, be moved to Albuquerque, New Mexico, where he worked as a janitor in a local Protestant church and devoted his free time to studying the history of the New Mexican land grants. Around 1963, he organized, with the assistance of his brothers, the Alianza Federal de Mercedes.

For a typical newspaper report of Tijerina's life history see Gruver, Tijerina Tells Life Story in Cruces Trial, El Paso Times, Nov. 10, 1967, at A-1, col. 2; Cook, Tijerina Testifies About Mexico Trips, El Paso Herald Post, Nov. 9, 1967, at A-1, col. 1.

4. E.g., N.Y. Times, June 7, 1967, at 1, col. 1. 
government agencies to respect traditional Spanish-American concepts of land ownership has caused many Spanish Americans to regard violence as the only effective way to avoid existing judicial precedents.

This Article, written from the viewpoint of a social scientist, examines in detail the legal, historical, sociological and economic causes of the land dispute in New Mexico and the impact of land loss on the Spanish-American community. Primarily, the Article illustrates the occurrence of extra-legal reaction when a legal system has ceased to be responsive to the legitimate expectations of a distinct and politically impotent minority. Hopefully, the perspective of a social scientist will lead to a more thorough understanding, and ultimately, to a just resolution of the legal questions raised by Spanish-American demands and grievances.

\section{I}

\section{CONFLICTING LAND SETTLEMENT PATTERNS AND}

ATTITUDES TOWARD LAND

\section{A. Spanish-American Settlement Patterns and Attitudes}

The Spanish Americans in New Mexico are the descendants of early Spanish colonizers, Mexican Indians from the Central Plateau of Mexico who were brought in by the Spanish as workers, and local Indian groups such as the Pueblo and Navajo. ${ }^{5}$ They vary in racial composition, dialect of Spanish, rural-urban residence patterns, and degree of involveinent with Anglo-American society from other Spanishspeaking groups in the Southwest. ${ }^{6}$ Creating the first European set-

5. Little scientific information exists on the racial characteristics of the SpanishAmerican people in New Mexico. The original Spanish settlers who were ethnically quite diverse, brought few women with them. They selected their wives from the various Indian groups among whom they lived. Groups of Mexican Indians from the valley of Mexico came into New Mexico as foot soldiers and workers. Sone early imtermixture took place between the Spanish and the Pueblo Indians but apparently very hittle has occurred during the past 100 years. Navajo and Apache women were made slaves and lived among the Spanish Americans leaving a mixed offspring. Early Anglo-American and French-Canadian trappers and American soldiers, cattlemeu, and traders married Spanish-American women. Their children were often reared as Spanish Americans. As a result many Spanish Americans have Anglo-American names. See J. BURMA, Spanish-Speaking Groups In the United States 4-5 (1954); C. McWilliams, North From Mexico, The Spantse-Speaking People of the United States 63-68 (1949).

6. An unfortunate tendency exists among many students of Spanish-American history and culture to apply the findings of one study to all of the Spanish Americans of northern New Mexico. The rather subtle differences that exist are often overlooked. See Knowlton, The Spanish Americans in New Mexico, 45 Sociology \& Social RESEARCH 448-54 (1961). The best overall treatment of the Spanish Americans can still be found in C. McWuliams, supra note 5. A valuable analysis of Spamish-American village culture is in J. BuRMA, supra note 5.

The base line against which social and economic change can be measured aniong the Spanish-American villages of the Rio Grande Valley, the heartland of the Spanish- 
tlement in what is now the United States, the colonizers and their descendants lived in isolation front other European groups for several hundred years ${ }^{7}$ and developed a rural farm village culture well adjusted to its natural environment. ${ }^{8}$

At the time of the American conquest of New Mexico, the majority of Spanish Americans lived in isolated, small, farming villages. The village economy was comprised of subsistence agriculture, handicrafts, livestock production, and sone trade with the Indians. ${ }^{\circ}$ Through

American region, is found in an excellent series of studies issued by the Southwest Region, Soil Conservation Series, U.S. Department of Agriculture, Albuquerque, New Mexico, in the late 1930's. Out of print and hard to find, these studies by Hugh C. Calkins, Tewa Basin Study, II: The Spanish-American Villages (1935); Reconnaissance Survey of Human Dependency on Resources in the Rio Grande Watershed (1936); A Report on the Cuba Valley (1937); Destruction of Village at San Marcial (1937); Notes on Community Owned Land Grants in New Mexico (1937); The Santa Cruz Irrigation District (1937); Rural Rehabilitation in New Mexico (1937); Tijeras CanyonMoriarity Area (1937); Village Dependency on Migratory Labor in the Upper Rio Grande (1937); Village Livelihood in the Upper Rio Grande Area and a Note on the Level of Village Livelihood in the Upper Rio Grande (1937), provide basic data on economic patterns, population size and composition, inpact and history of land loss, alienation of water rights, migration, social organization, and dependency on welfare among the Spanish-American village people of the Rio Grande Valley just before the advent of urbanization, industrialization, and the immigration of large numbers of Anglo Americans mito New Mexico during and after World War II.

George I. Sanchez in G. Sanchez, The Forgotten Prople (1967), has made a classical study of poverty, dependency, the failure of government programs, neglect, and the social impact of land loss in Taos County, New Mexico. Sigurd Johansen in S. Johansen, Rural Social Organization in a Spanish-American Culture Area (1948), adopting a narrower, more specialized approach, has provided sonne of the same type of data for the Spanish-American villages on the Rio Grande between Las Cruces, New Mexico and the Texas border. Olen E. Leonard has made an excellent study of the position of the land grant in the life of the Spanish-American villages. O. LEONARD, ThE Role of the Land Grant in the Social Organization and Social Processes of a Spanish-American Village in New Mexico (1948).

Other important studies providing useful information about the Spanish Americans are: M. Edmundson, Los Manitos (1957); A. Harper, A. Cordova \& K. Obero, Man and Resources in the Middle Rio Grande Valley (1943); C. LoOMis \& O. Leonard, Culture of a Contemporary Rural Communty: El Cerruto, New MeXico (1941); L. Perrigo, Our Spantsh Southwest (1960); L. Saunders, Cultural Differences and Medical Care of the Spanish Speaking People of the Southwest (1954); H. Ulibarri, The Effect of Cultural Differences in the Education of SpanIsh Americans (1958); Loomis, El Ceritto, New Mexico: A Changing Village, 33 N.M. Hist. Rev. $53-75$ (1958); Senter, Acculturation Among New Mexican Villagers in Comparison to Adjustment Patterns of Other Spanish Speaking Americans, 10 RURAL Socrology $31-47$ (1945); Walter, The Spanish-Speaking Community in New Mexico, 24 Socrology \& Social Research 150-57 (1939).

7. See C. McWILLIAMS, supra note 5, at 63-80.

8. For a discussion of the adaptation of Spanish-American villages to their natural environment see E. Maes, The World and the People of CundiYo 8-14 (1941).

9. See J. BURMA, supra note 5, at 3-19; H. UliBARR, supra note 6 , at 55-58; Walter; supra note 6 , at $150-57$. 
marriage, kinship bonds, and the god-father system-the compadrazgo $0^{10}$ - the inhabitants of each village were linked together in a small, cooperative, and often isolated peasant community. ${ }^{11}$ The world outside the village was viewed as dangerous and unpredictable. Lacking a sense of identification with any larger social grouping such as a region or an ethnic group, ${ }^{12}$ the people were reluctant to leave their villages.

The village by definition included not only the village proper but also the land belonging to the village inhabitants. ${ }^{13}$ During the Spanish and Mexican periods of New Mexico history, the mechanisin of the land grant was used by the Spanish and Mexican governments to convey public land into private ownership. Three types of land grants were made in New Mexico: the community grant, the sitio grant, and the proprietary grant. ${ }^{14}$ The community land grants were by far the most important type. ${ }^{15}$ Each community land grant was awarded to the heads of at least ten petitioning families. Once the

10. The compadrazgo is a Roman Cathohic religious and ceremonial mechanism that may be used to strengthen relationslips between friendly families, to create a patron-client relationship between a powerful person and those dependent upon him, or to enhance the relationship between related families. See Foster, Cofradia and Compadrazgo in Spain and Spanish America, 9 Southwestern J. OF ANTHRo. 1-28 (1953); Mintz \& Wolf, An Analysis of Ritual Co-Parenthood (Compadrazgo), 6 SoUTHWESTERN J. OF ANTHRo. 314-68 (1950).

11. "It is impossible to over emphasize the importance of the lome village to the Spanisl American. Most Hispanos [another name for the Spanish Americans] would be better off financially elsewhere and they know it. Yet they either remain in or return to the village as filings cling and return to a magnet." J. BURMA, supra note 5, at 7. See S. JohANSEN, supra note 6, at 91-130; G. SANCHEZ, supra note 6, at 3-14; Walter supra note 6 , at $150-57$.

12. J. BuRMA, supra note 5 , at 6-8, 27-28.

13. See Atencio, The Human Dimensions in Land Use and Land Displacement in Northern New Mexico Villages, in Indian and Spanish-American AdjUSTMENTs to ARID AND SEMI-ARID ENVIRONMENTS 44-52 (C. Knowlton ed. 1964); E. MAEs, supra note 8 , at 8-14.

14. The New Mexican land grants have received little scholarly attention. Probably the best overall treatment is C. Loomis, supra note 6 . William A. Keleher has covered Spanish, Mexican, and American law on land grants in Keleher, Law of the New Mexican Land Grant, 4 N.M. HIst. Rev. 350-71 (1929). Discussions of methods used by Anglo-Americans to obtain the land grants from their Spanish-American owners can be found in H. Brayer, William Blackmore: The Spanish-Mexican Land Grants of New Mexico and Colorado, 1863-1878; A Case Study IN the Economic StUdY OF the West 5-21 (1949); W. Keleher, The Fabulous Frontier 103-16 (1962). Material on the types and characteristics of the Spanish and Mexican land grants can be found in A. HARPER, supra note 6, at 18-19; C. Loomis, supra note 6, at 75-80; L. PERRIGo, supra note 6 , at 79-80.

15. For a discussion of the importance of the community land grant among the rural Spanish-American villages of New Mexico see J. BuRMA, supra note 5, at 3; A. HARPER, supra note 6, at 19-20; C. LOOMTS, supra note 6, at 79-80; G. SANCHEZ, supra note 6, at 6; S. MOSK, INFLUENCE OF TRADITION ON AGRICULTURE IN NEW MEXICo 34-51 (1942). 
grant was made, the cooperating families selected a village site, chose house lots, built a communal irrigation system, and divided among themselves the available irrigated farm lands. Each family owned its own house lot and croplands. The rest of the land in the grant was held in communal ownership known as the ejido. Every village family had the right to utilize the natural resources of the ejido and it could not be sold or otherwise alienated from the village. ${ }^{16}$ Sitio grants were large grants made to individuals for the purpose of developing hivestock ranches. These grants, although found in many parts of New Mexico, were most common in the eastern regions of the state. Proprietary grants were given to promiment individuals to thicken the zones of settlement or to protect approach routes to the areas of occupation. Their proprietors agreed in exchange for the land to secure settlers, erect churches, and provide military protection. As the population increased, a majority of the proprietary grants ultimately became community grants. ${ }^{17}$

The owners of the sitio and proprietary grants were rich and powerful individuals who controlled the economic, political, and military lives of the inhabitants of these grants. Being the dominant class of New Mexico, they worked their lands with workers drawn from two sourcesindebted Spanish-American peons who were not free to leave their einployers as long as they owed them money, and Indian slaves. Sons inherited the debts of their fathers. The inhabitants of villages located outside the huge grants often worked for the large landowners, thus becoming economically dependent even though they were legally free. ${ }^{18}$ In many inountamous and frontier regions, however, there were few large ranches and, consequently, the village people who inhabited the community grants in these regions were quite independent. ${ }^{10}$

Notwithstanding a state of peonage anrong the Spanish Americans who inhabited the proprietary and sitio grants, attended by ambivalent attitudes toward land ownership, the prevalence of community grants in New Mexico resulted in the development of distinct positive attitudes toward land among many of the rural Spanish-American village people. Land was not defined as a commodity or an investment but rather as the very foundation of hunran life. Families struggled to maintain their landholdings imtact from generation to generation. If a family

16. J. BURMA, supra note 5 , at 3 ; C. Looms, supra note 6 , at 79-80.

17. L. Perrigo, supra note 6, at 79-80; G. SANCHEZ, supra note 6, at 5 .

18. The best description of the life of the Spanish-American owners of the large ranches is found in F. CABEZA DE BACA, WE FED THEM CACTUS (1954).

19. See F. Swadesh, Hispanic American of the Ute Frontier from the Chama Valley to the San Juan Basin, 1694-1960 (unpublished doctoral dissertation in University of Colorado Library, 1966), for one of the best studies of the Spanish-American villages in the northern region where inany of the independent villages were located. 
lost its lands, the loss was perceived as tragic. Even today, SpanishAmerican families that move from New Mexico refuse to sell their village lands. ${ }^{20}$

\section{B. Anglo-American Attitudes and Usage}

In view of the different concepts of land ownership and usage among the Anglo-Americans who entered New Mexico, conflict with the Spanish Americans who were already there is hardly surprising. Land to the Anglo-American was a commodity to be bought and sold in the market like other commodities. Purchased as a financial imvestment, land was expected to imcrease sufficiently im value to yield a substantial profit when sold. In order to maximize profits, land owners felt free to exploit their property to obtain the highest short term economic gain even though adverse impact on neighboring property and on the public welfare was likely to result. According to Anglo-American conceptualization, land should be privately owned and private owners should pay property taxes. ${ }^{21}$ The concept of communal or public ownership was disfavored. Anglo-American attitudes toward land have been aptly stated as follows:

English settlers brought to the frontier ideas which precluded the sort of accomodation with nature and the native peoples that marked Spanish settlements from Florida to California, or the sort of self-contained agrarian economy descriptive of most of the French settlements. To the English immigrants, all of North America was a vast preserve of resources waiting to be processed. ${ }^{22}$

Venturing to New Mexico in search of economic opportunities, AngloAmericans found that the major sources of wealth-grazing, farm, mimeral and timber lands-were either owned or being used by Spanish Americans who did not share Anglo-American values regarding material progress, rapid development of natural resources, private ownership, and the accumulation of wealth. To gain access to wealth-producing lands, the Anglo-Americans had to wrest them froin the Spanish Americans. Their efforts to do so were largely successful and led to chronic and bitter land disputes which still fester in New Mexico. ${ }^{23}$

20. Few studies on the Spanish Americans contain material on Spanish-American attitudes toward the land. The subject is briefly discussed in Atencio, supra note 13.

21. For a succinct description of the American land tenure system from the point of view of a social scientist see Harris, Private Lands: Intra- and Inter-Private, in LAND Use Poltcy and Problems in the United States 307-35 (H. Otteson ed. 1963). For a legal description and history of the sane land tenure system see C. MoYNIHAN, INtroduction to the law of Real Property 11-27 (1962); R. Powell, Powell on REAL Property (rev. ed. 1969).

22. E. MURPHY, GOVERNING NATURE 7 (1967).

23. For material on the chronic land conflicts between Anglo-Americans and Spanish Americans in New Mexico see M. EDMuNDson, supra note 6, at 154; L. TIRE- 
The manner in which land was taken from the Spanish Americans involved primarily an interaction of political, legal, and economic factors. These factors-the causes of the land loss-will be discussed in Part II of this article. Part III will analyze the impact of the land loss on the Spanish Americans.

II

CAUSES OF THE LAND LOSS

\section{A. The Office of the Surveyor General and Congressional Bureaucracy}

The American government committed itself in 1848 at the end of the Mexican-American war by the Treaty of Guadalupe Hidalgo to protect the property and civil rights of the Spanish-speaking population inhabiting conquered territories. ${ }^{24}$ Congress did not, however,

Man \& M. Watson, La Comundad 11-13 (1943); Atencio, supra note 13, at 44-52; Walter, supra note 6 , at $150-57$.

24. The Treaty of Guadalupe Hidalgo that ended the state of war between the United States and Mexico was executed at the City of Guadalupe Hidalgo, Mexico, February 2, 1848. Articles Eight and Nine of the Treaty that guarantee the property rights and other liberties of the former Mexican nationals read as follows:

Article Eight-Rights of Mexicans Established in Territories Ceded to United States.

Mexicans now established in territories previously belonging to Mexico, and which remain for the future within the limits of the United States, as defined by the present treaty, shall be free to continue where they now reside, or to remove at any time to the Mexican Republic, retaining the property which they possess in the said territories, or disposing thereof, and removing the proceeds wherever they please; without their being subjected, on this account, to any contribution, tax, or charge whatever.

Those who shall prefer to remain in the said territorities, may either retain the title and rights of Mexican citizens, or acquire those of citizens of the United States. But they shall be under the obligation to make their election within one year from the date of the exchange of ratifications of this treaty; and those who shall remain in the said territories, after the expiration of that year, without having declared their intention to retain the character of Mexicans, shall be considered to have elected to become citizens of the United States.

In the said territories, property of every kind, now belonging to Mexicans not established there, shall be inviolably respected. The present owners, the heirs of these, and all Mexicans who may hereafter acquire said property by contract shall enjoy with respect to it, guaranties [sic] equally ample as if the same belonged to citizens of the United States.

Article Nine-How Mexicans Remaining in Ceded Territories May Become Citizens of the United States.

Mexicans who, in the territories aforesaid, shall not preserve the character of citizens of the Mexican Republic, conformably with what is stipulated in the preceding article, shall be incorporated into the Union of the United Sates and be admitted, at the proper time (to be judged of by the Congress of the United States) to the enjoyntent of all the rights of citizens of the United States according to the principles of the Constitution; and in the mean time shall be maintained and protected in the free enjoyment of their liberty and property, and secured in the free exercise of their religion without restriction.

Treaty of Guadalupe Hidalgo, Feb. 2, 1848, arts. VIII \& IX, 9 Stat. 922 (1848), T.S. No. 207 (effective July 4, 1848). 
consider the question of unsettled land titles in New Mexico until 1854. In addressing this question, Congress could have simply legalized Spanisl-American land grants held under Spanish and Mexican laws. Congress chose instead, however, on July 22, 1854, to reserve for itself the riglit to pass upon the validity of each land grant. ${ }^{25}$ Under the enacted procedure, the newly created office of Surveyor General of New Mexico was given the duty of securing data on the number of land-grant claims, their histories, their characteristics and their validity. The Surveyor General was also required to recommend to Congress through the Secretary of the Interior either approval or rejection of each land-grant claim. ${ }^{28}$ Corruption, inadequate staff and funds, and unfamiliarity with Spanish and Mexican laws and landholding traditions, rendered the office of Surveyor General of New Mexico unable to process fairly the numerous land grant claims. ${ }^{27}$ Moreover, althougl soine of its recommendations for approval of certain grants were accepted quickly, others were completely ignored. ${ }^{28}$ As one writer has noted: "[N] c claimant could secure congressional confirmation of his title unless provided with funds for a long sojourn at Washington, the organization of a lobby, and the buying of [an] army of official and nonofficial cormorants . . .."29 Thus under this procedure established by Congress for determining the validity of land grants the isolated, impoverished Spanish-American villagers, who knew nothing of Congress or of American laws, were unable to de-

25. Act of July 22,1854 , ch. 103,10 Stat. 308 . There is some evidence that by the time Congress acted the Spanish-American landowners were in the process of being victimized. A Catholic Sister of Charity resident in New Mexico before the Civil War made the following observation:

When the men from the states came out west to dispossess the poor natives of their lands, they used many subterfuges. One was to offer the owner of the land a handful of silver coins for the sinall service of making a mark on a paper. The mark was a cross, which was accepted as a signature, and by which the unsuspecting natives deeded away their lands. By this means, many a poor family was robbed of all its possessions.

B. Segale, At the End of the Santa Fe Trail 194 (1949).

26. Act of July 22,1854 , ch. 103,10 Stat. 308.

27. For a discussion of frauds and scandals associated with the early Surveyor Generals of New Mexico see Juhian, Land Stealing in New Mexico, 145 N. AM. REv. 17-31 (1887).

28. William A. Keleher makes the following observations regarding the functioning of the Surveyor General:

The Surveyor General was given a task entirely beyond the ability of any one man. Surveyor General after Surveyor General struggled with the flood of land grant claims that were filed in his office. Claims were approved or disapproved and reports were subinitted to the Secretary of the Interior, who in turn submitted reports to Congress. The Congess of the Umited States was not equipped with the machinery required to cope with the land grant problem. Some claims were confirmed off hand after a hurried study by meinbers of a committee. Other claims languished indefinitely, receiving no attention. W. Keleher, MaXwell LaNd Grant 7 (1964).

29. 2 R. Twitcheli, The Leading Facts of New Mexican History 467 (1912). 
fend their land titles effectively when challenged by Anglo-American claimants with funds to employ lawyers and maintain a lobby in Washington, or with friends in Washington political circles. ${ }^{30}$

\section{B. The Court of Private Land Claims}

In additon to being patently unfair, the congressional system of determining land titles, which depended heavily on the efficient functioning of the Office of the Surveyor General, did little to ehinmate defective titles. It soon became apparent that the defective titles to land grants covering a large part of southern Arizona, southern Colorado, and much of New Mexico were hampering the economic development of these territories. Faced with what one writer has termed "the greatest land embrogho in American history,"31 Congress established on March 3, 1891, a Court of Private Land Claims ${ }^{32}$ for the sole purpose of adjudicating land grant titles in Arizona, Colorado and New Mexico. Composed of five judges, the court met regularly until June 30, 1904. During this period, however, the court did not provide

30. William A. Keleher, the lawyer-historian of New Mexico, summarized the situation that came into existence as a result of the congressional scheme as follows:

The Alcalde [Spanish word for inayor] on the roof top in Las Vegas [New Mexico] must have grinned broadly as General Kearny [the American general in charge of the forces of occupation] spoke of protecting the people against the Indians, and protecting thein in their property rights. The fine promises Kearny made in Las Vegas were for the most part repudiated in Washington. Ignorance, stupidity, traditional red tape, an occasional bit of fraud, all had a place in federal government dealings with New Mexico. . . . General Kearny had promised the people of New Mexico security in their property; and the treaty of Guadalupe-Hidalgo, signed in 1848, promised the same thing. The government of the United Sates, however, failed to adequately execute that treaty .... The belief prevailed at the time of the signing of the Treaty of Guadalupe-Hidalgo, that if the government of the United States should claim any part of the Territory as public domam, it would at its own cost and expense, find out what it might be entitled to, and in doing this, necessarily ascertain the boundaries of private estates, whether called land grants or small homesteads.

The Congress of the United States required all claimants of lands under Spanish or Mexican grants to pay for their own surveys, to undertake and carry forward long, burdensome, and expensive procedures and litigation to perfect their titles. Litigation required the services of lawyers, and lawyers were quick to learn that they could exact important interests in land grants for professional work. Government officials, at times in the office of the Surveyor General of New Mexico, in the Commissioner of the General Land Office in Washington, were not adverse to whittling down acreage, to throwing out entirely genuine land grauts, on the pretext that they were fictitious and fraudulent. Mexican citizens soon found their estates in jeopardy. Many of thein . . . became pauperized as the result . . . of the failure of the United States of America to back up in good faith the assurances extended in the treaty of Guadalupe-Hidalgo.

W. KeLEHER, supra note 14, at 85-86.

31. Larson, Statehood for New Mexico, 1888-1912, 37 N.M. HIST. Rev. 161, 192 (1962).

32. Act of Mar. 3, 1891, ch. 539, 26 Stat. 854-62. 
a forum in which the illiterate, non-English-speaking Spanish-American village people could successfully defend their land titles. The costs of hiring an attorney, fighting a prolonged legal struggle, securing evidence, and finding witnesses were so high that many village people simply abandoned the legal battlefield and resigned themselves to the loss of their lands. ${ }^{33}$ Other village groups were forced to pay their attorneys in land.

Moreover, conflicting methods of defining land titles further disadvantaged the Spanish Americans in their attempts to defend their titles. According to Anglo-American property law, a valid land title was one that conferred ownership in writing and that could be traced in sequence of ownership from the first settler to the present owner. If the chain of title was not in order, the land title was defective. ${ }^{34}$ In contrast, Spanish and Mexican land titles and, therefore, SpanishAmerican land grant titles, were based more upon tradition and consensus than upon written deeds. Although the Spanish and Mexican governments did provide written deeds to land grant recipients, the deeds were not often preserved by the illiterate grantees and were ultimately lost. Copies of some of these deeds that were preserved in the Spanish and Mexican archives in Santa Fe were lost when the archives were partially destroyed by an early Anglo-American governor..$^{35}$ Many Spanish Americans beheve, as their predecessors did, that the destruction was deliberately carried out to eliminate written evidence of their land titles. $^{36}$ In any event, Spanish Americans without written evidence fared poorly in the newly created federal court.

The land loss which resulted from litigation in the Court of Private Land Claims was exacerbated by the fraudulent activities of some New

33. No written source exists for this statement. The data was derived from the author's discussions with several attorneys located at Las Vegas, New Mexico during his research on the land grants im this county in 1961. He was informed that many of these "ghost" landholdings exist in northern New Mexico. They were called ghost holdings as they were simply abandoned by their owners when their titles were challenged. It should be added that the inajority of anthropological and sociological articles, books, and studies of communities are based upon the authors' personal interviews and observations. They are checked by other students studying the same community and by internal consistency of reported data.

34. See W. Burby, Real Property §§ 130-34 (3d ed. 1965).

35. See C. Horn, New Mexico's Troubled Years 137-42 (1963) for a description of the partial destruction of the Spanish and Mexican archives of New Mexico by Governor William A. Pile in 1870.

36. Adolph F. Bandeher, the pioneer anthropologist and writer, found that the belief that Governor Pile had eliminated the New Mexican archives to destroy proof of Spanish-American land titles was widespread in New Mexico in the early 1880's. He wrote in a journal entry for August 25, 1880, "Padre Eguillon, very strong concerning the wanton destruction of the archives under Governor Pyle [sic], says it was done on purpose to destroy Mexican claims." C. LANE \& C. RILEY, THE SOUTHWESTERn JourNAIS OF ADOLPH F. BANDELIER, 1880-1882, at 73 (1966). 
Mexican lawyers. When Anglo-American immigration to New Mexico accelerated after the Civil War, many lawyers who sought better economic and pohtical opportunities were among the influx. By the 1870's, some of them assumed the leadership of a small group of Anglo-Americans and Spanish Americans who were known as the Santa Fe Ring. This Ring controlled much of the political and economic life of the territory from the 1870 's until the 1900 's ${ }^{37}$ Although the history, composition, and characteristics of the Santa Fe Ring have been poorly documented by New Mexican historians, the Ring was apparently formed by lawyers loosely associated with a prominent Santa $\mathrm{Fe}$ law firm that was active in the political and economic affairs of New Mexico from the 1870's until the 1900's. The lawyers during this period were generally better educated, more cohesive as a profession, more knowledgeable about territorial and national pohtical and economic trends, and more alert to busmess opportunities than most New Mexican ranchers, merchants, and farmers. It is not surprising, therefore, that lawyers played a dominant role in the Ring and in the general economic and poitical affairs of the territory and state of New Mexico during this period. ${ }^{38}$ In addition to prominent attorneys in nearly every part of New Mexico-some who were important Republican and Democratic leaders on the county, territorial, state, and national levels and others who were territorial, state, and federal judgesthe Ring ultimately included editors of major newspapers, businessmen

37. Robert Larson discusses the origin and composition of the Ring as follows: In New Mexico, there were probably not more than a thousand residents in the territory in 1850 who had been born in the United States and the population was then over 65,000 . Thirty-eight years later, in 1888, the Spanishspeaking people still held a inajority, but the number of easterners had swelled the so-called American population considerably. Many of these newcomers who flocked were farmers, while others were merchants or traders, not to mention the railroad men and those interested in mining. Of all who came, however, the group which was to play one of the most important roles influencing the course of New Mexico's fight for statehood proved to be the lawyerslawyers of varying capabilities, but almost without exception men who had strong opinions regarding statehood.

Many of the lawyers were quick to see what a vast fortune could be built in so rich a country. They looked with unrestrained ambition upon the obscure titles of ownership to thousands of acres in the territory. The original owners of the land had received their titles under the Spanish and then Mexican rule which preceded the Treaty of Guadalupe Hidalgo. Now, with many of the titles to these grants clouded in doubt after generations during which more and more nembers of the original family lived on the land, the American lawyers saw that they could use their legal skill to acquire a great deal of the land for themselves. Their success in this endeavor as well as in various other economic enterprises undertaken over the years was amazing. Because of the constant and close cooperation of these lawyers, their opponents soon labelcd thein as members of a "ring." The term generally referred to the Santa Fe Ring, although there were others of less importance.

Larson, supra note 31, at 161-62. For one of the best analyses of the Santa Fe Ring see H. LAMAR, The FAR SouTHWEST, 1846-1912, at 136-70, 185-98 (1966).

38. Larson, supra note 31, at 163. 
and bankers, various political officeliolders and land speculators. Although the Santa $\mathrm{Fe}$ Ring was headquartered in Santa $\mathrm{Fe}$, auxiliary rings sprouted in every county seat. The leaders of the Ring were Anglo-Americans, but many Spanish Americans who were eager for political prominence and economic success joimed them. Men who opposed the Ring failed to prosper in business or politics and some died violent deaths. ${ }^{39}$ Within a few years nembers of the Ring acquired vast acreages of land which had previously been owned by Spanish Americans. ${ }^{40}$

39. H. LAMAR, supra note 37 , at 189-98.

40. Id. at 139-51. One of the known leaders of the Santa Fe Ring, Thomas B. Catron listed his landholdings in 1893 as: two-thirds of the 78,000 acres of the Espiritu Santo Grant; one-half of the 21,500 acres of the Juana Lopez Grant; 24,000 acres of the Piedra Lumber Grant; 11,000 acres of the Gabaldon Grant; 15,000 acres of the Baca Grant; a portion of the Tierra Amarilla Grant; and 8,000 acres in patented homesteads. Catron's acquisition of au interest in the Tierra Amarilla Grant was the subject of a story iu a newspaper hostile to the dominant economic and political groupings of New Mexico at the time:

In 1832 what is known as the Tierra Amarilla land grant was made by the authorities of the Mexican government to Manuel Martinez, his eight sons, and their associates, who might desire to accompany them to take possession of and colonize the land. The grantees and their associates were prevented from taking immediate possession because of Indian hostilities. But within a few years they did take possession. On June 21,1850 , the [American] government confirmed the grant to Francisco Martinez, one of the eight sons of Manuel Marinez, then deceased and the representative of his brothers and their associate colonists. Immediately after confirmation, he gave the heads of all the families during the years 1860 to 1865 living on the grant deeds for pieces of land, agricultural land with the rights of economical and profitable irrigation. These deeds carried with them the right to pastures, water, wood, lumber, and free common roads through the entire grant. These people, one thousand of them, continued to live on this grant in coutentment until Thomas B. Catron appeared on the scene. During the latter sevcnties and early eighties, Catron acquired the interests in this grant of the eight sons of Manuel Martinez and of their descendents where the sons were dead. On August 17, 1883, he filed his bill im chancery in the office of the district court for this judicial district in Santa $\mathrm{Fe}$ in a suit to quiet title in this grant in himself and on the next day, August 18th, he served summons against 2,000 Mexican people living there under the above related circumstances. Summons was had by publication in the Springer Stockman, an English paper published at Springer in a different part of the territory entirely, and more than 200 miles away fom the grant, a paper in a different language, in a different part of the territory, and across the main range of the Rockics, no one single copy of which circulated in there at the tine. Catron was attending court in the country, knew the people, and made no effort to give them information. In fact he tried to conceal it. Title of the suit was directed against the unknown heirs of Manuel Martinez, Eusebio Martinez, Sixto Martinez, and all others claiming parts or interests in the Tierra Amarilla grant not mentioming the name of a single one of these people who were well known to him as residents of the grant. The suit was filed ou August 17th, suminons published next day, and on September 25th following, proofs of publication was made and on September 28th, just forty days after filing the suit a decree was made and entered declaring Catron's title to be perfect and absolute to every part and parcel of the grant except about fifty acres owned and cultivated by some of the heirs of Francisco Martinez which he excepted in his suit. The people knew nothing of this decree of court for ahnost seven years after it was entered when Catron pleaded it in a 


\section{Federal Settlement, Reclamation and Conservation Programs}

Federal programs designed to populate unsettled areas and to increase the acreage of irrigated land by building dams, developing irrigation projects, and protecting forested areas also took a heavy toll of Spanish-American landholdings. Anglo-American settlers moving into New Mexico after the Civil War found that most Spanish-American landholdings were classified as public lands because they were not registered in a federal land office. Lands so classified were open for settlement even though Spanish Americans had been using them for several hundred years. Anglo-Americans were able to secure perfect title to these lands under the Preemption Act of $1841,{ }^{41}$ the Hoinestead Act of $1862,{ }^{42}$ and the Veterans' Preference Acts of 1870 and 1872.43 Preenption was defined as: "the preferential right of a settler on public lands to buy his claim at a modest price."44 Under the Preemption Act of 1841, heads of families, widows, or single men over 21-who were American citizens or immigrants wlo liad filed a declaration of intent to become citizens-could settle a claim of 160 acres. The Act further required that they swear before a registrar that they liad not previously preempted under the Act and were not planning to sell the land for speculation, file a declaratory stateinent of intent

bar of action they brought against him to protect their pasture and timber rights.

People's Party Advocate, Oct. 22, 1892, at 3, col. 1.

Governor Prince, Governor of New Mexico, from 1889 to 1893, in his message to the State Legislature, December 28, 1892, stated:

In my last message, I endeavored to point out the dangerous character of the act to quiet titles. The object of this law is not objectionable but it can be abused in such a way as to defraud hundreds of land owners or unknown heirs, and then serving them by publication in some obscure newspaper or one published at a great distance from their residence, and in a language which they do not understand. I have heard of one case in which a party who had bought the interest of a single heir in a grant which had a multitude of owners thus employed this law and those interested never knew or heard of any suit until after a decree had been entered depriving them of their right.

The New Mexican, Dec. 28, 1892, at 1, col. 6.

41. Act of Sept. 4, 1841, ch. 16, \& 10, 5 Stat. 455.

42. Act of May 20, 1862, ch. 75, \& 1,12 Stat. 392. The following quotation from Keleher illuminates the harmful impact of the homestead laws on the Spanish Americans:

Froin Tularosa [a community in south central New Mexico], people of Spanish and Mexicau ancestry extended their settlements up and down the Pecos River and its tributaries, some of them building hoines near the Texas border. They were later deprived of much of the land upon which they settled, through chicanery, imposition and rough treatment by Texans, through their ignorance of the requirements of the liomestead law and by the indifference and neglect of both federal and territorial authorities.

W. KELEHER, supra note 14, at 104.

43. Act of July 15, 1870, ch. 194, § 25, 16 Stat. 320; Act of June 8, 1872, ch. 338,

$\S 1,17$ Stat. 333; B. HibBard, A History of THE PUBLIC LANd Policies 116-35 (1965).

44. P. Gates, History of Public Land Law Development 219 (1968). 
to settle within three months of settlement, build a shelter on their claim and cultivate it, and pay for the land at one dollar and twenty-five cents an acre within twelve months. ${ }^{45}$ The right of preemption was extended to settlers on unsurveyed public lands in all states and territories in $1862 .{ }^{46}$

Under the Homestead Act of 1862, those eligible to preempt public lands could secure, without paying consideration, title to a maximum of 160 acres of surveyed lands valued by the government at one dollar and twenty-five cents an acre or 80 acres of land valued at two dollars and fifty cents an acre. ${ }^{47}$ After filing their original application settlers were generally required to reside on the land within six months and occupy it for seven years before they had to make the fimal application whose approval vested title. ${ }^{48}$ Homesteaders were further required to build a shelter on their claims, cultivate the land, and pay the legal fees connected with transfering title. ${ }^{49}$

In 1870, Congress rewarded the veterans of the Civil War by permitting them to homestead 160 acres of land valued at two dollars and fifty cents an acre. ${ }^{50}$ In 1872, Congress passed the Soldiers and Sailors Act ${ }^{51}$ that allowed honorably discharged vetereans to count their period of military service as part of the time required to establish a homestead ${ }^{52}$ and to claim additional land contiguous to their homestead up to the maximum allowable holding of 160 acres. $^{53}$ Finally, on March 3, 1873, veterans were permitted by an additional act of Congress to assign their property rights ${ }^{54}$ and to locate homesteads on public lands not offered for sale. ${ }^{55}$ Veterans' rights soon become readily marketable because they could be used to obtain quick ownership of highly valuable lands. ${ }^{56}$

By preempting, homesteading, and purchasing veterans' rights, land-hungry Anglo-Americans obtained large quantities of land which were being used by Spanish-Americans. Unfamiliar with changing Anglo-American land laws, the Spanish Americans were seldom able

45. Act of Sept. 4, 1841, ch. 16, \$§ 9, 10, 12 \& 13, 5 Stat. 455.

46. Act of May 20,1862, ch. 75, §1, 12 Stat. 392.

47. Id.

48. P. Gates, supra note 44, at 294-95.

49. Act of May 20,1862, ch. 75, $\$ 2,12$ Stat. 392.

50. Act of July 15, 1870, ch. 194, \$ 25, 16 Stat. 320 .

51. Act of Apr. 4, 1872, ch. 85, \$ 1, 17 Stat. 49.

52. Id. \& 4.

53. $I d . \S 2$. 282.

54. Act of Mar. 3, 1873, ch. 283, $§ 1,17$ Stat. 609; P. Gates, supra note 44 , at 55. Act of Mar. 3, 1873, ch. 283, $\S 1,17$ Stat. 609; P. GaTes, supra note 44, at 282.

56. P. Gates, supra note 44 , at 282. 
to legalize their titles. ${ }^{57}$ Many Anglo-American homesteaders filed on waterholes in the semi-arid range lands forcing the abandonment of large grazing areas by Spanish Americans who were denied access to water. Unregisterd Spanish-American farm lands and even home sites in the villages were filed on by Anglo-American land seekers and speculators. ${ }^{58}$

Although hoinesteading and land preemption virtually ended during the 1920's, government programs established by the Bureau of Reclaniation and the United States Corps of Army Engineers further diminished Spanish-American land holdings. Irrigation projects to provide water for farmers in New Mexico, Texas, and Oklahoina were initiated by erecting dains on streams and rivers flowing out of the northern New Mexican mountams. Benefitted land was divided by the Bureau of Reclamation into irrigation districts. As urban settlenient increased, the Corps of Army Engineers created large flood control districts. Under both irrigation and flood control projects, the land included within the organized districts was burdened with fixed annual charges. Hundreds of Spamish-American subsistence farmers were unable to pay the charges and lost their lands through foreclosure. ${ }^{\text {50 }}$

The establishment of national forests in New Mexico also resulted in the abrogation of Spanish-American property rights. ${ }^{60}$ Much of the land now included in the National Forest System in northern New Mexico was once part of the many Spanish and Mexican land grants in the region. The inhabitants of the numerous Spanish-American nountain villages located their settlements in valleys and along streams wherever valley floors were large enough for village sites and irrigated farm plots. The forested niountains, usually part of the village cominunal lands or ejidos, were used for grazing, hunting, fishing, and obtaining firewood. When Anglo-Americans perfected title to the land grants, they usually conveyed the Spanish-American house lots and

57. V. Westphall, The Public Domain in New Mexico, 1854-1891, at 19 (1965).

58. Even the village sites themselves were not safe from aggressive homesteaders. See The New Mexican, July 20, 1889, at 4, col. 4.

59. See E. Fergusson, OUR SOUThWest 261-62 (1940); S. Johansen, supra note 6, at 25-26; Walter, supra note 6, at 150-57.

60. Harper, Cordova and Oberg report that the federal government from 1934 to 1943 acquired over one million acres of privately owned land grants and other tracts in the middle Rio Grande Valley, the heart of the Spanish-American area. See A. HArper, A. CORDOVA \& K. OBERG, supra note 6 , at 103. Most of this land must have gone into the national forest system. No studies have been made on the land acquisition methods of the Forest Service. The author has had numerous conversations with Anglo-American landowners, Spanish-American ranchers and village inhabitants, lawyers, and personnel of the Forest Service concerning the acquisition of former Spanish-Amcrican landholdings by the Forest Service. The facts and conclusions in this paragraph are based primarily upon these conversations. 
farm fields to the villagers who were using them. ${ }^{61}$ Often, the new owners permitted the village people to graze small herds of hivestock and to cut firewood on the former ejidos. ${ }^{62}$ When the Forest Service acquired these lands, these use rights were not acknowledged. The loss of grazing lands and the resources of the inountain forests brought poverty to large numbers of Spanish-American village people. $^{63}$

\section{The Effects of Local Economic Developments-Mercantile Capitalism and the Fixed Land Tax}

The Spanish-American rural village economy became increasingly dominated by mercantile capitalism until by the end of the 19th century, numerous merchants were well established in most of the larger villages. The people bought from the village merchants on credit and sold their products to the same merchants. The villagers seldom were aware of the exorbitant interest rates they paid or the state of their accounts. Many inerchants let custoiners go deeply into debt and then obtained judgments against them, forced the sale of their lands, and entered credit bids usually sufficient to acquire the property. A number of large landholdings were amassed in this manner. ${ }^{64}$

Further land loss was effected by the fixed land tax which was largely unknown under Spanish or Mexican law ${ }^{65}$ In a state such as New Mexico with its changing drought cycles and uncertain growing seasons, a tax system placing an annual tax unrelated to the fluctuating rural income can, in years of crop failures and low income, place severe financial burdens on an agricultural people. The land tax system imported into New Mexico from the humid east where the growing season was predictable, had a greater impact on the Spanish-Amercan subsistence farmers with few opportunities to earn money than it

61. Atencio, The Forest Service and the Spanish Surnamed American, in THE Mexican-American: A New Focus In Opportunty 35-38 (The Inter-Agency Comm. on Mexican-American Affairs ed. 1967); C. McWILliaMs, supra note 5, at 77.

62. Atencio, supra note 61 , at 35-38.

63. Id.; N. Gonzales, The Spanish-Americans of New Mexico 52-53 (1969).

64. In his study of mercantile capitalisn in New Mexico, Williain J. Parrish comments as follows on the opportunity of a merchant to exploit the Spanish Aunericans:

Before we attempt an appraisal of Cliarles Ilfeld's credit policy, however, we slould first appreciate the opportunities that lie possessed for the abuse of credit. His small agricultural customers, practically all of whom were uneducated and ill informed were easy prey for a man of resources, who through over extension of money and mercliandise loans could bring many of these people to do his bidding or force thein to relinquish their property.

W. Parrish, The Charles Ilfeld Company 84 (1961); Walter, supra note 6, at 150-57.

65. Keleher, Law of the New Mexico Land Grant, 4 N.M. HIST. Rev. 350-71 (1929). 
did on the more commercial, market-oriented Anglo-American farmers. ${ }^{66}$

Moreover, collection of the land tax was often subject to fraud. When grant owners were not able to pay taxes on commonly held grazing lands, the state took the property and sold it for less than the amount of the tax delinquency. Then, the new owner, through political influence, obtamed a reduction in the assessed valuation of the property. ${ }^{67}$ Many unfortunate Spanish Americans paid their land tax to county officials who pocketed the money, issued fraudulent receipts, and failed to record the payment in the county tax records. ${ }^{08}$ Some county officials in certain northern counties raised tax rates so high that few villagers could pay and then bought choice parcels of delinquent land at the subsequent tax sales. ${ }^{60}$ There is a feeling among villagers that even today, as a result of fraudulent tax collection, Spanish-American farmers who cultivate only a few acres are likely to pay a higher per acre tax than Anglo-American ranchers with extensive land holdings. ${ }^{70}$

\section{E. The Role of Violence}

Frontier violence inflicted by Anglo-American ranchers forced many Spanish Americans, especially in eastern and southern New Mexico, to abandon Spanish-American lands. ${ }^{71}$ A generally peaceful and unarmed people, the Spanish Americans were helpless against the influx of numerous Anglo-American cattlemen, primarily from Texas, who moved to the New Mexican ranges in the 1870's and 1880's. ${ }^{2}$ The Texans brought with them a hatred and contempt for all SpanishAmerican people. ${ }^{73}$ They murdered Spanish Americans, stole their

66. C. McWilliams, supra note 5 , at 77 .

67. E. FERGUSSON, supra note 59, at 260.

68. Many stories were related to the author about the alleged duplicity of county officials in land tax matters.

69. C. McWuliaMs, supra note 5, at 77.

70. During a series of interviews with 150 Spanish-American village people from 1958 to 1962 in San Miguel, Mora, Taos, and Guadalupe Counties, almost all of the villagers interviewed felt that there had been instances of fraud and deception in the collection of land taxes by county officials. Thus, Erna Fergusson states:

Buying up tax titles is also recommended for acquiring land. Often many owners of a grant are unable to pay taxes on their commonly held grazing lands assessed perhaps at a dollar and a half an acre. The state takes over the land for the delinquent taxes and resells the whole grant for thirty-five or forty cents an acre. Having influence the new owner then gets the assessed valuation reduced to fifty cents an acre.

E. Fergusson, supra note 59, at 260.

71. For evidence of the violence suffered by the Spanish Americans at the hands of Anglo-American cattlemen see W. GARD, FrontIER JUSTICE 90-91 (1949); Kenner, The Great New Mexico Cattle Raid, 1872, 37 N.M. Hrst. Rev. 243-58 (1962); Rasch, The Horrell War, 31 N.M. Hist. REv. 223-31 (1956).

72. W. KELEHER, supra note 14, at 107-11.

73. J. Culley, Cattle, Horses \& Men 21-22 (1940). 
land, rustled their cattle, and otherwise humiliated them whenever possible. ${ }^{74}$

As a result of these various causes of land loss, the ownership of enormous quantities of land passed from Spanish Americans to AngloAmericans and to state and federal governmental agencies. In the middle Rio Grande Valley of northern New Mexico, Spanish Americans lost, during the period between 1880 and the 1930's, over two million acres of private land and 1.7 million acres of communal land. ${ }^{75}$ Of this land, one million acres were taken by the state government, and more than one million acres were acquired by the federal government. ${ }^{76}$ While land loss in other sections of northern New Mexico was coinparable with the loss in the middle Rio Grande Valley, more severe losses occurred in eastern New Mexico. ${ }^{77}$ Part III of this Article will discuss the adverse effects of this alienation of land on the SpanishAmerican people and the nature of their response.

74. W. KeleHER, supra note 14, at 107-08. A prominent New Mexican rancher during the 1880's and 1890's aptly describes the attitudes of Anglo-American cattlemen toward the Spanish Americans of the time:

Now the general management and running of the ranch [The Bell Ranch in eastern San Miguel County, New Mexico] before the Eastern company acquired it and brought Arthur Tisdall from the Paloduro ranch in Texas to be general manager, had been in the hands of Western men of the old stamp, reared under pioneer principles. They believed in the strong arm, and there doesn't appear to have been any attempt to get the settlers [Spanish Americans] off the grant other than by scaring thein and doing them dirt whenever an opportunity showed up. As a result the feeling between the employees of the coinpany and the settlers was about as bad as it could be. One of the first things I warned about, on going down there, was to keep strictly out of the Mexican placitas [Spanish-American villages] or settlements, and never to go about the grant unarmed.

However, a short while after the new ownership came into effect it was decided to start a movement to get the settlers off the grant, and it fell to me to take the principal hand in this proceeding. ... I I did not have to the full the prejudice against Mexicans that prevailed almost universally among the cattlemen of the West. . . .

This attitude and state of feeling spread over the west froin Texas, along with the cattle business which originated there. Its roots were in the Alamo. ... [F]or the Texan of those days-it is true even of the present generation-the memory of that spot with its record of Mexican savagery kept alive a never failing flane of hatred and contempt for everything Mexican. As a consequence, the range men of those times treated the entire Spanish-American people as if they had no rights at all; refused to have any social relations with them, although some were of proud Spanish blood, killed them, dispossessed thein of their lands, scattered their sheep, and drove off their cattle. The Mexicans, being without any means of self-defense, became completely cowed and browbeaten.

J. Curlex, supra note 73, at 20-22.

75. A. HARPER, supra note 6, at 103.

76. Id.

77. See N. Gonzalez, supra note 63, at 54; Calkins, Village Dependency on Migratory Labor in the Upper Rio Grande, supra note 6, at 1-53; Calkins, Reconnaissance Survey of Human Dependency on Resources in the Rio Grande Watershed, supra note 6 , at 28. 


\section{III}

\section{IMPACT OF THE LAND LOSS}

\section{A. Development}

The massive loss of land destroyed the base of the SpanishAmerican rural village economy which was primarily dependent upon subsistence agriculture, livestock raising, and utilization of the natural resources of the forested uplands. Numerous Spanish-American males were forced to become migrant sheep herders or field workers throughout the west while their families remained in New Mexico to farm small irrigated plots. ${ }^{78}$ Without grazing land for their hivestock, Spanish-American villagers were deprived of animal food products such as meat, milk, butter, and cheese, with the result that malnutrition became prevalent. ${ }^{79}$ During the depression of the 1930's, large numbers of Spanish Americans who were unable to fimd employment in the migrant stream were forced to remain in the villages. ${ }^{80}$ Many others returned to their native villages after losing their jobs in the urban centers. As population pressure upon diminishing land resources sharply increased, crop failures due to a prolonged drought brought the village people to the end of their resources. ${ }^{81}$ They were rescued from destitution by New Deal programs such as the Public Works Administration, the Federal Emergency Relief Administration, and the Works Progress Administration, which provided food and limited employ. ment. $^{82}$

During World War II, federal employment agencies recruited and trained Spanish Americans for work in the newly established defense industries, on military bases, and in federal installations in Arizona, New Mexico, California, Colorado, Utah, Oregon, and other western states. $^{83}$ Such einployment opportunities were limited however, for although federal imstallations in the central Rio Grande Valley in New Mexico provided einployment for village people within recruiting distance, northern New Mexico was largely bypassed by private and government industry alike during World War $\Pi .^{84}$ Many people found

78. G. SANCHEZ, supra note 6 , at 64 .

79. M. Pijoan \& R. Roskelley, Nutrution and Certain Related factons of Spanish Americans in NorTh Colorado 16-19 (1943).

80. Calkins, Rural Rehabilitation in New Mexico, supra note 6, at 4; Calkins, Village Dependency on Migratory Labor in the Upper Rio Grande, supra note 6, at 1-3.

81. Calkins, Village Livelihood in the Upper Rio Grande Area and a Note on the Level of Village Livelihood in the Upper Rio Grande, supra note 6, at 3-4.

82. J. BURMA, supra note 5, at 18; Calkins, Village Livelihood in the Upper Rio Grande Area and a Note on the Level of Village Livelihood in the Upper Rio Grande, supra note 6 , at 1-4.

83. Loomis, Wartime Migration from the Rural Spanish Speaking Villages of New Mexico, 7 RuRAL Sociol. 384-95 (1942).

84. Id.; C. Loonis \& N. Loomis, Skilled Spanish-American War-Industry Workers 
employment outside the village as migrant or mine workers. The draft took large numbers of young Spanish Americans from the villages. Their remittances and allotments provided economic security for the first time to many village families. ${ }^{85}$

Although many Spanish Americans returned to their villages after the war, the majority remained in the cities and towns on the West Coast and in the Rocky Mountain states where employment opportunities and economic conditions were better than in northern New Mexico. ${ }^{86}$ The letters they wrote and the stories they told during their visits home prompted migration of thousands of village people to the urban centers of the West. ${ }^{87}$ The migrants spoke little English and lacked the occupational skills, education, and familiarity with AngloAmerican society necessary for success in an urbanized English-speaking environment. ${ }^{88}$ This continuing migration of rural Spanish Americans has augmented serious urban problems in California and other western states such as the expansion of slums and ghettoes, increased crime and juvenile delinquency, increased dissolution of families, unemployment, under-employment, and welfare. ${ }^{89}$

In addition to exacerbating urban problems elsewhere, the Spanish-American exodus from New Mexico has failed to solve the basic economic and social problems of northern New Mexico. Largely bypassed by the economic stimulus of World War II and the Korean War and by the growing industrialization and urbanization of much of the western United States which began during the 1950's, northern New Mexico remains impoverislied. The region is marked by poverty, unemployment, poor roads, an inadequate educational system, dependency on welfare, high rates of tuberculosis and other diseases, and governmental neglect. Although controlled by the United States for over 100 years, the Spanish-American people of northern New Mexico

from New Mexico, 2 APplied ANTHRo. 33-39 (1942). The major federal installations in northern New Mexico during World War II were the atomic research installation at Los Alamos and the Sandia Corporation concerned with atomic weaponry in Albuquerque. Workers in the middle Rio Grande Valley found employment in these plants, but distances were so great that few Spanish Americans in other areas could commute.

85. N. GONZALEZ, supra note 63, at 125-26; Loomis, supra note 83, at 384-95.

86. N. GonZalez, supra note 63 , at 125-26.

87. Id. at 126-28.

88. F. Mittelbach \& G. Marshall, The Burden of Poverty 19-36 (1966).

89. See the following studies for the urban migration of Spanish Americans: W. Fogel, Mexican Americans in Southwest Labor Markets (1967); F. Mtrtelbach, \& G. Marshall, supra note 88; J. Samora \& R. Lamanna, Mexican Americans in a Miwest Metropolis: A Study of East Chicago (1967); L. Shanno \& E. KRASS, THe ECONOMic ABsorption and CULtural Integration of ImMigrant WoRKERs (1966); N. Kurtz, Gatekeepers in the Process of Acculturation (unpublished doctoral dissertation in University of Colorado Library, 1966). 
have not shared in the productivity of the American economic system. ${ }^{90}$

\section{B. The Spanish-American Response}

\section{A History of Protest}

Although the Spanish Americans have been generally a peaceful people regardless of the frequent violence used against them, ${ }^{91}$ there is some evidence of a continuous historical pattern of protest organizations which have employed violent tactics. ${ }^{92}$ The members of these organizations have cut fences, burned buildings, and destroyed livestock in an attempt to frighten intruding Anglo-American ranchers away. ${ }^{08}$

90. The following studies and reports contain data on socio-economic conditions in northern New Mexico: Maloney, Recent Demographic and Economic Change in Northern New Mexico, 17 N.M. Bus. 2-13 (1964); J. Burma \& D. Williams, An Economic, Social, and Educational Survey of Rio Arriba and Taos Counties (mimeographed report prepared for the Northern New Mexico College, no date). Additional material can be found in the following publications: New Mexico Business; New Mexico Labor Market Trends; and in the inontbly and quarterly reports of the New Mexico Department of Public Welfare, Santa Fe, New Mexico. These reports carry data on juvenile delinquency, the socio-economic conditions of the older population and statistics on the number of welfare cases for each county.

91. See notes 71-74 supra and accoinpanying text.

92. No studies are in existence on the formation and decline of Spanish-American protest organizations. The first organization about which any information is available was known as the White Cap Movemeut. It arose, in San Miguel County in the early 1880's as Anglo-American ranchers moved into the Las Vegas Land Grant. From there it spread into most of the counties of northern New Mexico. Little is known of its leaders, methods of organization, or patterns of operations except that farm and ranch buildings were burnt, fences cut, and Anglo Americans warned to leave. See the almost daily account of its activities in the Las Vegas Daily Optic and The New Mexican from 1889 to 1893 . The following newspaper story is typical of the period:

At midnight about seventy-five on horseback, disguised and armed, rode into town and tarried awhile about the county jail, going thence to the residence of District Attorney Miguel Salazar. No acts of violence were done, but the appearance of the inen were [sic] generally construed as intended for a menace to the court officials. The appearance of this body of mysterious men [in Las Vegas, New Mexico] created no little excitement in the town and on Saturday morning the district judge called in the grand jury and from the bench spoke at length on the subject. The court said that recently a certain party of San Miguel County was warned to leave his liome and property on pain of death, a similar body had come in the night to his premises to make sure he had obeyed their order. That later on William Rawlins of Las Vegas had been similarly terrorized, his fences cut, and his herder shot through the leg, and he driven away from his home to take refuge in Las Vegas. That another man had been attacked at his home in the day time by a similar armed body.

The New Mexican, Nov. 4, 1889, at 4, col. 2.

During the 1930's an organization about which even less is known named the Liga Obrera de Habla Espanol (League of Spanislı-Speaking Workers) was present in the Spanish-American villages. See Calkins, The Tewa Basin Study, supra note 6, at 17. The Tierra Amarilla Land Grant heirs became active in the 1950's admonishing all "squatters" to leave the area. See N.Y. Times, June 4, 1967, at 81, col. 2.

93. See note 92 supra. 
Very seldom were any Anglo-Americans killed. ${ }^{94}$ Local, state, and federal law enforcement agencies have continually suppressed the protest organizations by incarcerating the leaders, killing them, or forcing them to leave New Mexico. ${ }^{95}$ As a result, the organizations gradually ceased to exist. Although Anglo-Americans tended to forget them, the Spanish Americans kept the activities of the organizations and the names of their leaders alive in folk songs and stories. ${ }^{96}$ Then, as new causes of unrest fermented and a new generation assumed leadership, the cycle began once again. Thus, Reies Lopez Tijerina and his Alianza Federal de los Pueblos Libres ${ }^{97}$ are part of a discernible pattern of leaders and protest organizations.

\section{A Modern Catalyst-The Role of the Forest Service}

The chronic unrest among the rural Spanish-American village people began to increase sharply during the period between 1964 and 1967 when the Forest Service banned the grazing of nilk cows and work horses on national forest lands and sharply reduced the number of cattle and sheep allowed to graze there. ${ }^{98}$ The livelihood of large numbers of rural Spanish-American village people depended on subsistence farming on five to twenty-five acre parcels and grazing livestock in neighboring national forests that for the nuost part had once been. part of community land grants. ${ }^{99}$ When permitted to graze their milk

94. No study has ever been made of the history, characteristics, causes, and leadership of Spanish-Americau protest organizations. For material on the White Caps, one of the earliest and most notorious of such organizations, see The New Mexican from Dec. 14,1889 , to June 18,1896 . The daily editions for these years were full of material on the White Caps and their activities. Some material on the White Caps, Mano Negro (Black Hand) and similar protest groups can be found in R. GARDNER, GRITO 72-84 (1970). For data on Spanisli-American protest organizations active in recent years in the Tierra Amarilla area, see M. JENKINSON, TIJERINA 47-57 (1968).

95. For additional material on the White Caps and the death of its major leader read Rev. Stanley, Desperadoes of New Mextco 279-80 (1953).

96. No collection of these songs or stories has, unfortunately, ever been made. The Spanish-American history of New Mexico has been sadly neglected. The author has heard unany stories of the White Caps in Las Vegas, New Mexico and listened to many songs about them and about Reies Tijerina and the Alianza. The composition of Corridos, or songs that relate a story, is still an active folk art in New Mexico.

97. See notes 1 \& 3 supra.

98. A good discussion of the mcrease in tensions in northern New Mexico is found in M. Jenkinson, supra note 94, at 47-57. Perhaps the most concise discussion on the Forest Service Regulations and their role in triggering violence can be found in the following newspaper articles: Akers, Forest Service Is Not "Bad Boy," The New Mexican, June 18, 1967, at B-1, col. 6; The Albuquerque Tribune, June 22, 1967, at A-1, col. 5; Windes, Legitimate Differences on Use of Forest Land, The New Mexican, July 9, 1965, at A-1, col. 4.

99. The best analysis of the subsistence farming economy of the Spanish-American villages is found im the studies by Hugh $\mathrm{C}$. Calkins cited in note 6 supra. See especially, Tewa Basin Study II: The Spanish-American Villages; Reconnaissance Survey 
cows in the national forests, the Spanish-American farmers had been able to supply their families with dairy products from their milk cows and sell the surplus milk, butter, and cheese in the surrounding communities. When prohibited from grazing their cows, the farmers lost an important source of dairy products and revenue. Since they could not afford to purchase dairy foods in any abundance, their families suffered. ${ }^{100}$

To aid them in growing crops for family consumption, the Spanish Americans grazed their work horses on land included within the national forest. Lacking the fimancial means to purchase tractors and other farm equipment, the farmers simply could not remain in agriculture without the use of their work horses. Moreover, the refusal to grant grazing permits for Spanish-American work horses while AngloAmerican ranchers were permitted to graze riding stock seemed discriminatory to the Spanish Americans. ${ }^{101}$ In diminishing the number of cattle and sheep that could be grazed on the national forests, the Forest Service deprived the villagers of an important source of food and wool. ${ }^{102}$

The impact of these decisions on the village people was severe. As their living standards declined, existing malnutrition became a more serious problein. ${ }^{103}$ Many were forced out of an agricultural way of life and had to migrate. When the people complained to Forest Service officials, they were told that the cutbacks and terminations were necessary because the forests had been overgrazed. ${ }^{104}$ This explanation was not fully believed, however, because many Spanish-American leaders were aware of the fact that the Forest Service was spending more money to develop picnic and camping grounds, hiking trails, and recreational facilities than it was spending to improve the grazing and carrying capacity of the forest ranges. ${ }^{105}$ Bitterness and hostility to

of Human Dependency on Resources in the Rio Grande Watershed; Village Livelihood in the Upper Rio Grande Area and a Note on the Level of Village Livelihood in the Upper Rio Grande.

100. See note 98 supra.

101. See note 98 supra.

102. N. GonZALEZ, supra note 63, at 122; Wolff, Culture Change in Loma: A Preliminary Research Report, 50 OHo J. OF SCIENCE 53-59 (1950).

103. Conversations between the author and village families affected by Forest Service Regulations brought an adinission that some families were purchasing powdered milk but no butter or cheese while inembers of other families stated that they could not afford to buy dairy products. Several public health nurses in Rio Arriba County stated that they felt that malnutrition was increasing among the school children in the communities bordering the National Forests in that county.

104. Interviews with Spanish-American grazing permit-holders on the Kit Carson National Forests in the communities of Mora, Pecos and Las Vegas in 1961.

105. In 1968, 240,753 dollars was proposed for range and re-vegetation while $1,235,823$ dollars was conımitted to recreation in New Mexico. Atencio, supra note 61, at 37 . 
the Forest Service began to spread widely in northern New Mexico. ${ }^{106}$

\section{The Rise of the Alianza-Prelude to the Courthouse Raid}

When appeals to the Forest Service, other federal agencies, and the state government went unheeded, many of the village people turned in desperation to Reies Lopez Tijerina and the Alianza. ${ }^{107}$ Formed around 1963, the Alianza first attracted only poor, elderly, formerly rural Spanish-American migrants who had come to reside in the urban slums of Albuquerque and Santa Fe. The situation began to change around 1965 when bitter Spanish-American villagers, disaffected young adults, and some veterans began to join the Alianza. ${ }^{108}$ The Alianza message was simple and direct and said in effect: You have been robbed of your lands, your grazing rights, your language, and your culture by Anglo-Americans and their Spanish-American accomplices. No one in government will leelp you. Join us. Together we will get your land back and your grazing rights restored. This will preferably be done by court procedures, but it will be done one way or another. ${ }^{109}$

The strategy of the Alianza was also simple and perhaps naive. Its leaders decided to focus their efforts on the national forests in order to secure the support or at least the friendly neutrality of the SpanishAmerican rural population while not arousing antagonisin among the Anglo-Americans which would have been likely to result from an attack on private landholdings. Lacking funds to litigate the titles to privately held lands, Alianza leaders hoped to force the Forest Service into a legal confrontation in which the Service would be forced to prove its title to land included in the national forests in northern New Mexico. Selecting an area in the Kit Carson National Forest that was once part

106. A Spanish-American resident of northern New Mexico said:

It is not uncommon for the native population to see the forest ranger in his olive drab uniform as an American occupational trooper guarding the spoils of the Mexican-American war. The injnstices of the past are manifested in the attitudes of the northern New Mexican commoner. There is an enemy in those Id. at 36 . hills. It is that forest ranger.

107. R. GARDNER, supra note 94, at 114-19.

108. The author attended almost every annual meeting of the Alianza from 1964 to 1968 in the capacity of a participant observer. The people in attendance at the 1964 meetings were middle-aged and elderly Spanish-American inhabitants of the Albuquerque slums, accompanied by a few older inhabitants of nearby Spanish-American villages. By 1966, the composition of the audience had changed. The rural immigrants, who because of poverty and land loss had moved from the rural villages to the Albuquerque slums, were noticeable but outnumbered by younger Spanish-American farmers, veterans, and teenagers. The messages of the speakers were more militant, the demands more insistent, and the tendency toward militant action unmistakable.

109. The Alianza goals expressed here are a composite of statements made by Alianza leaders at their annual meetings in 1966 and 1967. 
of a land grant, Tijerina announced that a Spanish-American rural community to be known as the Pueblo Republica de San Joaquin del Rio Chama - the Community Republic of St. Joaquin of Rio Chamawas to be established and would assume all the land rights of the original community land grant made to a group of settlers on August 1, 1806 , by the Spanish government. ${ }^{110}$ To draw public attention to the new community, a group of Alianza members conducted a camp-in in the San Joaquin grant area. The campers elected a community council, a mayor, a judge, a sheriff, and deputies, and the new government posted "no trespassing" signs. Much to the disappointment of the community members, the Forest Service ignored their camp-in.111 The following weekend, October 22, 1966, another camp-in was conducted. Two forest rangers, one Forest Service imvestigator, and five state police officers stationed themselves at the campground entrance where the rangers tried to collect camping fees. When an altercation broke out between the rangers and some of the community people, the rangers were seized by the crowd. Tijerina and several leaders took the rangers from the crowd and presented them before the community judge who found them guilty of trespassing and ordered them out of the campground. The state police did not interfere.

The following Wednesday, Reies Lopez Tijerina, his brother Cristobal, and other Alianza members were arrested on a federal warrant and charged with assault and battery and expropriation of government property. ${ }^{112}$ The origiual charges were found defective, withdrawn, and replaced by new charges. Venue was changed froin the friendly atmosphere of Rio Arriba County to the chillier atmosphere of Albuquerque, and then to the hostile atmosphere of Anglo-American southern New Mexico. ${ }^{113}$ The trial finally began Noveinber 6, 1967, in Las Cruces, New Mexico, and the defendants were found guilty of

110. A good account of the sequence of events during the camp-ins and the confrontation with the forest rangers can be found in M. JENkINSON, supra note 98, at 63-66; R. GARDNER, supra note 94 , at 127-28.

111. R. GARDNER, supra note 94 , at 128-31.

112. For the sequence of events following the encounter with the Forest Service see Albuquerque Tribune, Nov. 5, 1967, at A-5, col. 3; Albuquerque Journal, Nov. 6, 1967, at A-1, col. 6; Albuquerque Tribune, Nov. 6, 1967, at A-1, col. 8; Albuquerque Journal, Nov. 7, 1967, at A-1, col. 8; Albuquerque Tribune, Nov. 7, 1967, at A-1, col. 8; Albuquerque Journal, Nov. 8, 1967, at A-1, col. 8; id., Nov. 9, 1967, at A-1, col. 1; Albuquerque Tribune, Nov. 9, 1967, at A-1, col. 8; id., Nov. 10, 1967, at A-1, col. 1; Albuquerque Journal, Nov. 10, 1967, at A-1, col. 3; Weber, Spanish Americans Demand Their Rights, Christian Science Monitor, Nov. 10, 1967 at 3, col. 1; Albuquerque Tribune, Nov. 11, 1967, at A-1, col. 8; Albuquerque Journal, Nov. 11, 1967, at A-1, col. 4; id., Nov. 12, 1967, at A-1, col. 2.

113. The New Mexican, Nov. 5, 1967, at A-1, col. 3; id., Nov. 7, 1967, at A-1, col. 7; id., Nov. 8, 1967, at A-1, cols. 1 \& 3; id., Nov. 9, 1967, at A-1, col. 4; id. Nov. 10, 1967, at A-1, col. 1; id., Nov. 11, 1967, at A-1, col. 5; id., Nov. 12, 1967, at A-1, col. 6 . 
assaulting two forest rangers and of converting government property to private use. ${ }^{114}$ Reies Tijerina was sentenced to two years in jail, his brother Cristobal to two years with 18 months suspended, and two other defendants to 60 days. The case was appealed, and the defendants were released on bail. ${ }^{115}$

During the fall of 1966 and the spring of 1967 the tempo of events accelerated. Homes, barns, and hay stacks owned by AngloAmerican ranchers were burned and the ranchers were warned to abandon northern New Mexico. Many Anglo-Americans who had lived in the northern villages for many years in peace and harmony with their Spanish-American neighbors moved their families out because of the increased hostility. ${ }^{116}$ Reies Lopez Tijerina announced that the Alianza was prepared to take direct action. At a series of meetings in Albuquerque, the federal and state governments were strongly attacked, the federal and state court systems in New Mexico were vilified, and Spanisl1-American political leaders were characterized as "Tio Tacos."117 Finally, a inass meeting was called by the Alianza at which direct action programs were to be presented. The meeting was set for June 3, 1967 at a small Spanish-American village in north central New Mexico named Coyote. Fear began to spread throughout northern New Mexico and Anglo-American ranchers hired private gunmen to patrol their lands. ${ }^{118}$

David Cargo, a maverick Republican Governor of New Mexico, was elected in 1966 after securing considerable Spanish-American support from those who were disillusioned because of the neglect of northern New Mexico by the regular party organizations. Cargo, shortly before his election, married a Spanish-American woman who was a former member of the Alianza Federal de Mercedes and began to visit Spanish-American villages and listen to the often bitterly expressed complaints about governmental neglect and village problems of the Spamishspeaking inhabitants. ${ }^{119}$ The Governor suggested programs to improve conditions in northern New Mexico that did not secure the support of

114. Albuquerque Journal, Nov. 12, 1967, at A-1, col. 2; El Paso Times, Nov. 12, 1967, at A-1, col. 2.

115. The New Mexican, Dec. 15, 1967, at A-1, col. 3; El Paso Herald Post, Dec. 15, 1967, at A-1, col. 1; id., Dec. 16, 1967, at C-1, col. 4.

2.

116. M. JenKinson, supra note 94, at 48-50; N.Y. Times, June 4, 1967, at 81, col.

117. Many of the political leaders of New Mexico had sought Alianza support in the elections of 1966. After the raid, all denied ever having requested it. None came to the assistance of the Alianza leaders once the court proceedings lad begun. Private conversations with polical observers in New Mexico brought this out very clearly. In resentment, the Alianza leaders attacked the politicians of New Mexico shortly after the affair with the forest rangers in very strong language, little of which reacled the press.

118. N.Y. Times, June 4, 1967, at 81, col. 2; Akers, Daylight Raiders Leave Bloody Path, The New Mexican, June 6, 1967, at A-1, col. 2.

119. N.Y. Times, June 4, 1967, at 81, col. 2. 
the Democratic controlled legislature. The Governor was greatly distressed by the social and economic conditions of the Spanish Americans but was never able to develop a program that would improve their situation primarily because his relations with the state legislature and the heads of many state agencies were poor. Governor Cargo negotiated with Alianza leaders the night before the Coyote meeting in an attempt to persuade them to postpone the meeting until tensions had cooled. ${ }^{20}$ He warned them that District Attorney Alfonso Sanchez was already circulating literature warning that peaple who attended the Coyote meeting would be arrested but offered to attend a delayed meeting if it were peaceful. ${ }^{121}$ The Governor's attempts to mediate were nullified by the arrest of several Alianza leaders. After issuing orders for the arrest of additional Alianza leaders and of Alianza members found carrying arms, he flew to Michigan to meet with Governor Romney. ${ }^{122}$

Several hours after the Governor's departure, District Attorney Alfonso Sanchez and State Pohce Chief Joseph Black broadcasted that the Coyote meeting was banned. They denounced Reies Lopez Tijerina and other Alianza leaders as radical agitators, ridiculed Alianza members as dupes, and threatened to arrest any member who came near Coyote. ${ }^{123}$ Arrest warrants were issued for Tijerina and his colleagues. Road blocks went up and people were stopped and arrested. Tijerina and the majority of the Alianza leaders who slipped through the road blocks felt betrayed by the state government and decided to send a raiding party to attack the Tierra Amarilla courthouse, to release their imprisoned members and to make a citizens' arrest of Alfonso Sanchez. ${ }^{124}$

Confusion became rampant in Santa $\mathrm{Fe}$ as news of the raid reached the state capital. Rumors spread that Alianza guerrilla bands led by Cuban guerilla experts were moving toward the city, that urban Alianza cells were preparing to revolt, and that enormous caches of heavy weapons were hidden in the northern hills. ${ }^{125} \mathrm{Na}$ -

120. R. GARDNER, supra note 94 , at 154 .

121. Id.

122. Akers, Daylight Raiders Leave Bloody Path, The New Mexican, June 6, 1967, at A-1, col. 2; Albuquerque Journal, June 8, 1967, at A-1, col. 1.

123. The New Mexican, June 5, 1967, at 3, col. 4.

124. Jorgensen, Northern Sections Tense, The New Mexican, June 8, 1967, at A-1, col. 1; Albuquerque Journal, June 9, 1967, at G-10, col. 1; El Paso Times, June 6, 1967, at A-1, col. 1; El Paso Times, June 7, 1967, at A-1, col. 4.

125. On the afternoon of the day of the raid, the author was asked by several members of the executive branch of the state government of New Mexico to come to Santa $\mathrm{Fe}$ to serve as a mediator between the state government and the Alianza. He accepted the request and very early Tuesday morning a state plane picked him up in El Paso. Upon arrival in Santa Fe he found the state capital filled with the rumors narrated in the text. A small group was formed to assist in reducing tensions and preventing further violence. The author was taken blindfolded and accompanied by a 
tional guardsmen with tanks and artillery were hastily sent into the mountains and were joined by Anglo-American members of the New Mexico Mounted Patrol and the Apache Tribal Police from Dulce. Guardsmen and state police swept through many Spanish-American villages breaking into homes without warrants. They held many men, women, and children for long hours in a sheep corral in Canjilon without any food or water except the contaminated water found in a sheep tank.126 Although no state of emergency or martial law was ever declared, a large part of northern New Mexico was treated as though it were an enemy country in the process of being occupied.127

\section{CONCLUSION}

The events associated with the subsequent raid liave become history and are rapidly fading from the public consciousness. Yet, tensions remain and the police presence is very conspicuous in northern New Mexico. Although Reies Lopez Tijerina is now serving federal sentences at Leavenworth and has yet to serve his state sentences, he remains the most important Spanish-American leader in New Mexico. With the force of his own charisma, he has broken through the feelings of powerlessness and apathy of the rural and urban SpanishAmerican masses. He has made the land issue a focusing point for Spanish-American resentments, frustrations, and aspirations. His raid on the courthouse and the legal maneuverings on the part of the prosecutors in the various state and federal trials ${ }^{128}$ have made him

blindfolded newspaper reporter, Peter Nabokov, to Reies Lopez Tijerina's place of concealment to ascertain the plans of the Alianza. Tijerina stated that the Alianza desired no further violence, and that its members who were accused of any violation of the law would like to surrender with the assurance that they would be taken alive. This was reported to state officials. The governor was advised to demobilize the National Guard and send the Apache Tribal Police and the Anglo-American mounted patrols home and to thin out the state pohice. Within a few days the Alianza members had turned themselves in or had been picked up by the police. An excellent account of the raid, the recent visit to Tijerina and its aftermath can be found in P. NABokov, TiJERINA AND THE Courthouse Raid (1969). See also Knowlton, Guerrillas of Rio Arriba: The New Mexican Land War, 206 The NATION 792-96 (1968).

126. Akers, supra note 122; Akers, Tierra Amarilla Wasn't as Peaceful as It Looked, The New Mexican, June 6, 1967, at A-5, col. 1; Denver Post, June 8, 1967, at 3, col. 1; The New Mexican, June 7, 1968, at A-1, col. 7; Albuquerque Journal, June 6, 1967, at A-1, col. 5; Albuquerque Tribune, June 6, 1967, at A-1, col. 7; Denver Post, June 6, 1967, at 3, col. 1; id., June 7, 1967, at 3, col. 1; N.Y. Times, June 7, 1967, at 4, col. 1; Albuquerque Journal, June 7, 1967, at A-1, col. 4; Denver Post, June 9, 1967, at 37, col. 1; id., June 10, 1967, at 26, col. 7; El Paso Times, June 6, 1967, at A-1, col. 8; id., June 6,1967 , at A-1, col. 4.

127. See note 126 supra; R. GARDNER, supra note 94, at 164.

128. Albuquerque Journal, Jan. 4, 1968, at A-1, col. 7; id., Jan. 4, 1968, at A-1, col. 6; id., Jan. 9, 1968, at A-1, col. 8; Nabokov, Court to Try Press: Forget It and Write, The New Mexican, Jan. 30, 1968, at A-1, col. 4; The New Mexican, Feb. 2, 1968, 
the hero of militant Mexican-American and Spanish-American groups throughout the Southwest. The position of the traditional AngloAmerican and Spanish-American leadership in New Mexico has been seriously eroded. Anglo-American and Spanish-American communities have drifted apart. Gunmen patrol the fence lines of the isolated Anglo-American ranchers whose buildings and hay stacks have been burned. Young, militant, Spanish-American leaders are appearing in the streets of the urban slums, in the corridors and classrooms of high schools and colleges, and in the rural villages. Middle-class SpanishAmerican lawyers, teachers, and social workers are taking a more millitant position on educational, legal, and welfare issues that concern Spanish-Americans. New Mexico has entered a period of uncertainty marked by the possibility of further violence. The development of state and federal programs to improve economic conditions in northern New Mexico, upgrade local school systems, create a bilingual and bicultural society in which the language of the Spanish Americans would be respected, and prograins which eradicate the urban slums would certainly reduce tensions, but they would not bring social peace to New Mexico. Until the Spanish-American village people secure the return of all or part of the community land grants taken from them or, at the very least, receive adequate financial compensation for the lost lands, unrest and social tensions will continue to exist.

The behef that traditional institutions are affected by pressure through estabhished and legitimate channels has been a release valve when discontent among a people begins to boil. Failure of that valve can be expected, almost as a matter of certainty, to lead to violence. A community psychology is created by a sense of political and legal powerlessness and that psychology is destructive. At some point specific grievances become secondary to a sense of collective helplessness, and at that point, the demands of the group may be willfully sacrificed to its need to attack the unresponsive and degrading legal institutions. There is more than ample evidence that this psychology is present in the Spanish-American people in New Mexico, and therefore, unless the legal and political institutions of that state can re-establish and legitimate theniselves in the eyes of this constituency, continued and increasing violence is probable. The state government can accomplish such legitimation only by reopening the entire question of land grant ownership and incorporationg traditional Spanish-American concepts of land ownership into existing property law.

at A-1, col. 1; Albuquerque Journal, Feb. 8, 1968, at A-1, col. 6; id., Apr. 29, 1968, at A-1, col. 8; id., Nov. 12, 1968, at A-1, col. 2; id., Nov, 16, 1968, at A-1, col. 1; id., Nov. 21, 1968, at A-1, col. 1; id., Nov. 7, 1968, at A-1, col. 5; id., Nov. 29, 1968, at A-1, col. 1; id., Dec. 6, 1968, at A-1, col. 1; id., Dec. 11, 1968, at A-1, col. 7; id., Dec. 14,1968 , at A-1, col. 7 . 